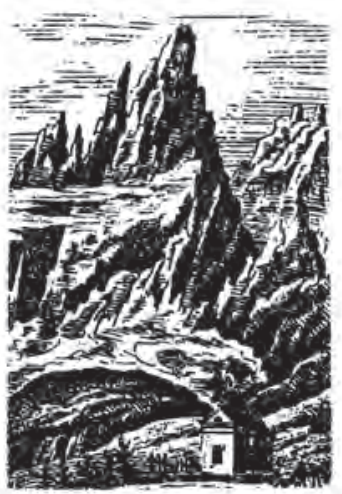

Katarzyna Król

ORCID: 0000-0002-0684-0049

katarzynabeatakrol@wp.pl

https://doi.org/10.19195/2084-4107.13.26

\title{
Apeniny we wspomnieniach Anieli Walewskiej
}

Słowa-klucze: Apeniny, historia, turystyka, literatura, pamiętnikarstwo

Keywords: Apennines, history, tourism, literature, memoir writing

\section{The Apennines in Aniela Walewska's memoirs}

\section{Summary}

Kilka chwil we Włoszech w latach 1847 i 1848 [A few Moments in Italy in 1847 and 1848], a volume of memoirs published in 1850 and written by Aniela Walewska - a forgotten author of the Romantic era - is a historically, culturally and socially interesting travel account which, in addition to notes devoted to the political situation at the time, also features descriptions of cultural and natural landscapes which Walewska had an opportunity to admire during her Italian voyage. Particularly worthy of note are her reflections concerning mountain landscapes reflecting the author's romantic sensibility as well as her emotional and aesthetic attitude to new places. Spending a few weeks in the Tuscan resort of Bagni di Lucca, Aniela Walewska had an opportunity to admire the Apennines, which generated admiration and lofty feelings in her and prompted her to engage in existential, philosophical and religious reflection. Using a variety of means of literary expression, the writer sought to convey the varied aspects of the mountains: solemn beauty, picturesque charm, severe and wild appearance. Yet despite her lively interest in the Apennine landscapes, the Polish traveller was preoccupied primarily with the political situation in her distant homeland, which determined her 
perception of and feeling for the mountains so much that her observations often departed from purely aesthetic evaluation in favour of patriotic associations. However, the descriptions in her memoirs are vivid, full of admiration and rapture, which makes them worthy of being brought back from obscurity and analysed thoroughly. As evidence of individual and feminine way of experiencing the world of nature, they certainly make a valuable contribution to the Romantic travel literature and expand our knowledge of the history of mountain voyages of Polish women in that period.

Aniela z Kuszlów Walewska (zm. 1873) ${ }^{1}$, publikująca pod pseudonimem Wanda Odrowąż i Bożenna ${ }^{2}$, należy do grona zupełnie zapomnianych dzisiaj polskich pisarek, których biografia i działalność literacka wymaga podjęcia dogłębnych, opartych w głównej mierze na materiałach archiwalnych, studiów. Wydaje się bowiem, że praca źródłowa nie tylko pozwoli wydobyć dawne literatki $z$ cienia niepamięci, lecz także doprowadzi do sformułowania nowych postulatów, wzbogacających naszą dotychczasową wiedzę na temat ich życia i twórczości.

Warto zatem zwrócić uwagę na pominięty milczeniem dorobek literacki Walewskiej, którego lektura może okazać się badawczo użyteczna. Za szczególnie godny zainteresowania należałoby uznać zbiór wspomnień zatytułowany Kilka chwil we Wtoszech w latach 1847 i $1848^{3}$, będący relacją z ponadrocznego pobytu autorki w Italii ${ }^{4}$.

Głównym powodem przedsięwzięcia przez nią zagranicznej podróży mogły być wydarzenia mające miejsce w latach czterdziestych XIX wieku na terenie Galicji — niewykluczone, że opuszczając rodzinny Kraków, zamierzała uniknąć austriackich represji związanych z klęską powstania 1846 roku. Podjęcie decyzji o wyruszeniu w kierunku Półwyspu Apenińskiego ułatwiło zapewne pragnienie

1 Aniela z Kuszlów Walewska ogłosiła drukiem wspomnienia z podróży Kilka chwil we Włoszech w latach 1847 i 1848 (Poznań 1850), powieści: Stefania. Powieść dzisiejsza (Wilno 1853) i Uprzedzenia. Powieść oryginalna (Warszawa 1862) oraz streszczenie dzieła Antoine'a-Frédérica Ozanama Les poètes franciscains en Italie au treizième siécle jako Franciszek Seraficki i poeci włoscy z jego szkoły (Kraków 1854). Postać Anieli Walewskiej nie funkcjonuje jednak w dyskursie literaturoznawczym, aczkolwiek jej istnienie odnotowują między innymi: K. Estreicher, Bibliografia polska XIX stulecia, t. 5, Kraków 1880, s. 8, s. 120; Encyklopedja powszechna [S. Orgelbranda], t. 9, Warszawa 1901, s. 87; D. Kudelska, Juliusz Stowacki i sztuki plastyczne, Lublin 1997, s. 137; L. Bernardini, Polska podróżniczka w Lukce w czasach ekscentrycznego księcia Karola Ludwika Burbona, [w:] Iter Italicum. Sztuka i historia/Arte e Storia, red. M. Wrześniak, Warszawa 2011, s. 395-413; M. Wrześniak, Florencja-muzeum. Miasto i jego sztuka w oczach polskich podróżników, Kraków 2013, s. 364; M. Berkan-Jabłońska, Weredyczki, sawantki, marzycielki, damy... W kręgu kobiecego romantyzmu. Studia i szkice z kultury literackiej kobiet okresu międzypowstaniowego, Łódź 2019, s. 10, 13, 36, 38, 41, 114, 118, 119, 182, 256, 259; M. Zbrzeźniak, Polskie peregrynantki we Wtoszech. Portret Italii, jej kultury i mieszkańców, [w:] Życie prywatne Polaków. „Portret kobiecy”. Polki w realiach epoki, t. 1, red. M. Korybut-Marciniak, M. Zbrzeźniak, Łódź-Olsztyn 2014, s. 25, 35.

${ }^{2}$ E. Minkowiecki, Wykaz pseudonymów używanych przez autorów polskich, Warszawa 1881, s. 9; L. Czarkowski, Pseudonimy i kryptonimy polskie, Wilno 1922, s. 19, 61; Stownik pseudonimów i kryptonimów pisarzy polskich oraz Polski dotyczacych, t. 3, oprac. A. Bar, Kraków 1938, s. 127; Stownik pseudonimów pisarzy polskich, red. E. Jankowski, t. 1, Wrocław 1994, s. 291.

3 W. Odrowąż [A. Walewska], Kilka chwil we Włoszech w latach 1847 i 1848, Poznań 1850.

${ }^{4}$ Aniela Walewska przebywała we Włoszech od stycznia 1847 do maja 1848 roku. 


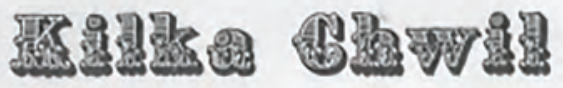

we

\section{Wloszech}

\section{w Iatach 184 i 1848}

\author{
przez
}

\section{Wande Ddrowąż.}

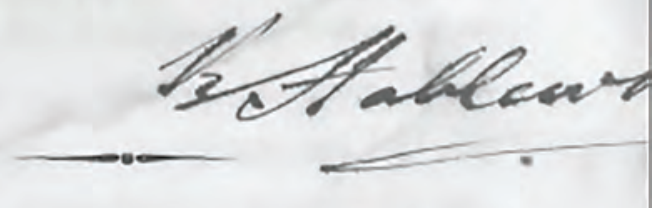

Poznań,

W komisie Księgarni J. K. '̇́apáskiego.

$1 \overline{850}$.

1. Okładka książki A. Walewskiej, Kilka chwil we Włoszech w latach 1847 i 1848, Poznań 1850, ze zbiorów Biblioteki Kórnickiej, https://www.wbc.poznan.pl/dlibra/ publication/125608/edition/135485/content (dostęp: 12.02.2019) 
poznania jego uroków — „niekwestionowanego centrum sztuki, kultury i nauki nowożytnego świata" 5 . Z kart wspomnień pisarki dowiadujemy się, że podczas swojej bytności we Włoszech była mocno zintegrowana z polskim środowiskiem, co znacznie wpłynęło na sposób postrzegania przez nią ówczesnej rzeczywistości. Mimo zatem żywego zainteresowania pamiętnikarki, jakim obdarzała otaczający ją krajobraz kulturowy i naturalny, sytuacja polityczna odległej ojczyzny nieustannie zajmowała jej uwagę, o czym świadczą poszczególne fragmenty wspomnianych zapisków - sprawy narodowe determinowały tak ogląd świata polskiej podróżniczki, że zanotowane przez nią refleksje wielokrotnie odbiegały od czysto estetycznej oceny na korzyść patriotycznych skojarzeń.

Relacje z włoskiego wojażu stanowią również świadectwo romantycznej wrażliwości ich autorki, której emocjonalne i poetyczne nastawienie w odbiorze nowo poznawanej przestrzeni znalazło odzwierciedlenie między innymi w opisach natury. Jednym z potwierdzających to przykładów są fragmenty wspomnień poświęcone górskim krajobrazom - interesujące wydają się zwłaszcza zapiski pochodzące z końca wiosny i początku lata 1847 roku, kiedy Walewska przebywała w cieszącym się wówczas dużą popularnością kurorcie Bagni di Lucca. Pierwsza wzmianka na temat jej pobytu w toskańskim uzdrowisku pojawia się pod datą 29 maja:

Po dwumiesięcznej przerwie napełnionej osobistym smutkiem biorę znów za pióro. Piękne to miejsce, prawdziwa oaza w tej porze roku, gdzie gorąco dokuczliwem się staje; nazywają Szwajcaryją Włoską ten śliczny zakątek, tę dolinę, niebotycznemi górami otoczoną, tysiącznemi strumieniami odświeżoną. Mieszkamy na wysokiej górze Bagni caldi, w domu noszącym nazwę: Casa Lena. Od wczorajszego dnia mam fortepian i salonik osobny; grając, patrzę na cudny widok, i w każdej chwili zejść mogę do ładnego ogrodu, zupełnie odosobnionego, dziwnej, szczególnej postaci, jaką w dawnych zamkach widzieć tylko można. Cały ten pałac ma cechy starożytności, podobno z klasztoru przerobiony. Co też jest korytarzów, przejść skrytych i odkrytych, schodków, balkonów różnej wielkości i formy! Zbłądzić by można w tym czystym labiryncie. Temu lat kilka, jakbym szczęśliwą tu była, z jaką radością bym biegała, wyszukiwała wszędzie wszystkiego, dodając myślą, ustrajając w tajemnicze sceny wszystkie te miejsca. Teraz zaś czuję i widzę, że piękne - lecz inaczej to czuję, bez tej ciekawości gorączkowej, bez tego zachwycenia, upojenia, które tyle dodaje wdzięku pięknym obrazom. Patrzę i uwielbiam wprawdzie te arcydzieła ręki Boga, które gdzieniegdzie nam zostawił, jakby próbki tego, co tam będzie!... jakby mownice, z których do nas przemawia głosem tak silnym i wzniosłym, że i dusze nasze odrywa od ziemskich znikomości i myśl napełnia wyższem, świętszem pragnie-

5 Cyt. za: M.E. Kowalczyk, Zagraniczne podróże Polek w epoce oświecenia, Łomianki 2019, s. 60 . 
niem; lecz się patrzę łzawo i spokojnie, nie żądam koniecznie, aby biegać i bujać po tych górach i dolinach, stąpać po tych ruinach i kwiatach, dotknąć się ręką tych kryształowych wód i strumyków. Patrzę się, lecz smutne jakieś zadziwienie i żal czuję gorzki, że tak wszystko się śmieje, kiedy dla nas wszystko zgasło na świecie, i że natura w tak godowe szaty przybrana, kiedy nas tylko smętarze, wspomnienia ścigają ${ }^{6}$.

Zanotowane przez Walewską pierwsze zdanie przywołanego fragmentu Kilku chwil we Włoszech... stwarza pewne trudności interpretacyjne, których rozwiązanie przyniesie dopiero znajomość biografii autorki. Analiza tekstów źródłowych dotyczących w większym bądź mniejszym stopniu jej życia dowiedzie, że powodem „osobistego smutku” była śmierć siostry pisarki - Józefy z Kuszlów Doria-Dernałowicz (zm. 1847)7 . Można zatem przypuszczać, iż kilkutygodniowy pobyt w Bagni di Lucca miał charakter nie tylko rekreacyjny, lecz także terapeutyczny. Sposób postrzegania i odczuwania górskiej przestrzeni, jaki daje się zauważyć w przytoczonej relacji, ujawnia estetyzującą i refleksyjną — choć niepozbawioną egzaltacji - postawę młodej literatki. Co znamienne, w malowniczym położeniu toskańskiej miejscowości dostrzegała ona znamiona arkadyjskie, stanowiące dla niej źródło inspirujących wrażeń i doznań. Zachwycona urzekającymi walorami krajobrazu, z pasją oddawała się grze na fortepianie, marzeniom i rozmyślaniom w emanującym aurą tajemniczości ogrodzie. Jako admiratorka pięknych widoków widziała $\mathrm{w}$ nich zarówno najdoskonalsze dzieło sztuki, którego twórcą jest Bóg, jak i zapowiedź niebiańskiego raju. Mimo jednak odwołań do idyllicznej i sakralnej interpretacji górskiego krajobrazu pamiętnikarka nie zapomniała o sytuacji narodowej. Jak słusznie zauważył Luca Bernardini:

piękno natury okolic Lukki paradoksalnie wzbudza w pisarce lęk, ponieważ urok miejsc tak zwanej Szwajcarii lukkańskiej napawa smutkiem wypływającym ze wspomnień odległej ojczyzny. [...] podróżniczka nie czuje się moralnie uprawniona, by w pełni cieszyć się doznaniami estetycznymi dostarczanymi przez krajobraz tak, jak mogłaby to robić jeszcze kilka lat wcześniej. [...] Kontemplacja bujnej natury oraz malowniczego krajobrazu „toskańskiej Szwajcarii” przynosi nie ukojenie, lecz pobudzenie duszy rozjątrzonej przez hydrę wspomnieńn ${ }^{8}$.

Trudno nie zgodzić się z opinią włoskiego badacza, zwłaszcza że zorientowana w kulturze i literaturze europejskiej pisarka potrafiła w sposób plastyczny zobrazować podziwiane widoki, co potwierdzają między innymi pozostawione przez nią opisy morskich pejzaży ${ }^{9}$. Postrzeganie górskiej przestrzeni przez pryzmat patriotycznych wątków byłoby zatem świadomym zabiegiem literackim,

\footnotetext{
${ }^{6}$ W. Odrowąż [A. Walewska], op. cit., s. 9-10.

7 Zob. Józefa Kuszel z Hulidowa h. Drogosław, www.sejm-wielki.pl (dostęp: 12.02.2019).

8 Cyt. za: L. Bernardini, op. cit., s. 399-400.

9 Por. W. Odrowąż [A. Walewska], op. cit., s. 2-3, 19-21.
} 
nie zaś dowodem braku zdolności estetycznego przeżywania piękna natury i nieumiejętności oddania jego istoty ${ }^{10}$. Ponadto, wbrew sądom Luki Bernardiniego, pamiętnikarka nie tylko dostrzegała i podziwiała urodę górskich krajobrazów, lecz także czerpała z niej duchowe korzyści. Kontemplacja piękna natury pozwalała jej odnaleźć spokój i zapomnienie od dręczących ją trosk, co ujawniła w zapisie z 2 czerwca:

Narzekać na nią [naturę - K.K.] jednak nie można, bo jej wpływ jednostajny, uroczy, balsamem na rany; a żyjąc z nią tylko, boleść największa, jeżeli nie pociechę, to ukojenie znaleźć musi ${ }^{11}$.

Niezwykle interesująco prezentuje się również relacja opatrzona datą 8 czerwca:

Jakże miło tak marzyć, dumać! Jak lubą jest ta samotność i cichość, przerywana tylko tysiącznemi głosami natury, czarującem migotaniem luciolów (robaczków świętojańskich), które jakby gwiazdki oświecają te góry. Jeden z nich zajrzał tu do mnie; lecz widząc, że przy świetle gaśnie jego piękność i nie błyszczy nią, odleciał, opuścił mnie. Czyż z ludźmi nie to samo?... Na ciemnolistych krzakach lauru lub cyprysu czepiają się, kryją; goniłam za niemi. Noc czarująca, powietrze balsamiczne, szum Serchia przygrywa dziwną harmonią; do rana siedziałabym w ogrodzie. Wczoraj byliśmy w Prato Fiorito; ładne miejsce, które wszyscy oglądają, pomimo odległości i dróg okropnych. Nie można się inaczej tam dostać tylko na koniu lub ośle, lecz droga cała tak malownicza, że się zapomina o utrudzeniu. Widok Ferreny, zamku z borgiem, a później Fedelice przepyszne, cudownie krajobrazy odsłania. Dojeżdżając tylko do niego, natura na chwilę zdejmuje swe szaty piękne i błyszczące, a w oddartych, ponurych się pokazuje, dziką postać przybiera, by tem więcej później zachwycać. Prato fiorito bowiem (ta góra słusznie tak nazwana, bo na wiosnę cała kwiatami okryta) otoczone jest górami, skałami, różnemi wyskokami natury; nad wszystkiem jednak wznosi się jej wierzchołek kwiecisty i pozwala objąć oczyma daleki i wspaniały widnokrąg. Nie tylko Apeniny śniegami gdzieniegdzie okryte, ale najdalsze punkta; Liworno i morze, widzieć się czasami dają; chmura jednak, ten tak rzadki gość na italskiem niebie, przeszkadzała mi je dojrzeć. Niemniej jednak zachwycił mnie wspaniały widok Apeninów, jeziór, boryków, różnych dróg do Modeny pięknie się wijących, i Serchio, którego z rzeką Limą widzieć można; wszystko to złączone $\mathrm{z}$ balsamicznem powietrzem, z melodyjnemi dzwonkami paszących się kóz, przykuło mnie do miejsca;

10 Potwierdzeniem estetycznej wrażliwości i pisarskich ambicji Anieli Walewskiej, a także odzwierciedleniem jej fascynacji górską przestrzenią jest relacja z przebytej przez nią trasy Szczawnica-Szmeks. Zob. Bożenna [A. Walewska], Wycieczka z Szczawnicy do Szmeks, „Dziennik Warszawski" 4, 1854, nr 338, s. 4-6.

11 W. Odrowąż [A. Walewska], op. cit., s. 11. 
siadłam pod drewnianym krzyżem, wzniesionym na najwyższym punkcie, i zatopiłam się w myślach. Czy przebiegałam tę krainę cudowną, rozkoszną, która mi tyle jeszcze swych skarbów pokaże? O nie! dziwną jakąś sprzecznością Karpaty nagle przypomniały mi się, przesuwając przed oczy różne szczegóły pamiętnej mi po nich przejażdżki i ten cudny wieczór, gdy dojeżdżając do Nowego Targu, podziwiałam tych gór śnieżne szczyty, blaskiem księżyca oświecone. Ustępy z Normy ${ }^{12}$ przez towarzyszy śpiewane wtórowały moim myślom. Helena coś cicho szeptała o Alpach, Apeninach, a ja marzyłam, że tam piękniej, prawda; lecz czy lepiej?... ${ }^{13}$

W pierwszej kolejności należałoby zaznaczyć, że ten fragment wspomnień dowodzi wieloaspektowego przeżywania górskiej przestrzeni. Walewska, zafascynowana otaczającym ją światem natury, z nieukrywanym zachwytem rejestrowała różnorodne doznania zmysłowe - zarówno optyczne, akustyczne, jak i olfaktoryczne. Podziwiając widoki z perspektywy wysokogórskiego wzniesienia, dostrzegała ich malownicze komponenty, które wraz z dźwiękowymi i zapachowymi walorami skłoniły ją do zadumy. Co ciekawe, drewniany krzyż nie wzbudził w podróżniczce reakcji charakterystycznych dla romantycznego doświadczenia gór - wywołał obraz minionego wydarzenia, nie zaś chęć do rozważań eschatologicznych. Pragnienie ujrzenia ojczystych terenów, tęsknota za ich widokiem okazały się silniejsze niż myśli o sprawach ostatecznych. Trzeba jednak przyznać, że zamyślona, siedząca na wzniesieniu pod drewnianym krzyżem postać kobieca znakomicie wpisywałaby się w charakter twórczości romantycznego malarza Caspara Davida Friedricha. Pisarka, aby oddać sensualność podziwianych widoków, posłużyła się różnorodnymi środkami literackiej ekspresji — wprowadziła do opisu między innymi personifikacje natury, obrazujące zróżnicowane oblicze górskiej przestrzeni: jej wzniosłe piękno, malowniczy urok, surową i dziką urodę. Można również odnieść wrażenie, że w przytoczonej relacji pobrzmiewa nuta fascynacji nocnym krajobrazem - ulubioną scenerią romantyków, sprzyjającą marzeniom, rozmyślaniom i wizjom. Interesujące, że w poczynionych przez Walewską zapiskach pojawiają się także refleksje natury filozoficznej. Szczególnie urokliwe wydają się rozważania, w których autorka przywołuje motyw robaczków świętojańskich (świetlików), zwanych przez nią luciolami (wł. lucciola).

Jak zostało już wspomniane, symbol drewnianego krzyża wzniesionego na szczycie góry nie zachęcił podróżniczki do przemyśleń na temat sensu ludzkiego życia i śmierci. Odmiennie prezentuje się jednak treść zapisu z 30 czerwca:

12 Aniela Walewska wspomina o operze Norma (1831), do której libretto napisał Felice Romani (1788-1865), a muzykę skomponował Vincenzo Bellini (1801-1835). Źródłem literackim opery był dramat Alexandre'a Soumeta (1788-1845) Norma, albo dzieciobójstwo (1831). Jej światowa premiera odbyła się 26 grudnia 1831 roku w Mediolanie, w Polsce można było ją obejrzeć dopiero w 1843 roku w Warszawie.

13 Ibidem, s. 11-13. 
Pochmurny dzień dzisiejszy; jednak ulubiony zwyczajny mój spacer odbyłam konno. O! co za rozkosz tak pędzić cwałem na tej drodze tak uroczej, jakby zawieszonej nad różnemi światami. Przebiegając je, wzrok się gubi to w przepaściach zielonych, uśmiechających się prawie, to w odartych, kamieńmi wysłanych. W jedne spogląda się co chwila; te kwiaty tam ciągną magnetycznie; od drugich z drzeniem odwraca się oczy. Czemuż? Wszakże w obydwóch jednaka śmierć i zagłada. Lecz ta odarta ze swych złudzeń, sina i straszna; tamta tuląca się miękko, jakby usłana w marzeniach, nadziejach uroczych. Czyż życie nie to samo? Wszędy droga cierpień i krzyża; dla jednych kwiatami się zakrywa, dla drugich kolcami sterczy. Lecz w ostatniej chwili jednako odarte, skaleczone są członki; jednakie znużenie, otrętwienie całej istoty ${ }^{14}$.

Łatwo zauważyć, że Walewska podczas konnej przejażdżki po górach z ciekawością spoglądała w przepaści i rozpadliny, które postrzegała jako nie tylko niebezpieczne, lecz także tajemnicze. Znamienne, że ich widok wzbudził w pisarce pesymistyczne myśli i skłonił ją do egzystencjalnej zadumy. Zastosowane przez nią środki artystycznego wyrazu znacznie wzbogaciły opis doświadczanych emocji i wrażeń, czyniąc go plastycznym oraz sugestywnym.

Obfitujący w inspirujące doznania kilkutygodniowy pobyt w Bagni di Lucca zakończył się, zanotowaną 4 lipca, następującą refleksją:

Jutro wyjeżdżamy. Żal mi bardzo tego miejsca. Ten ulubiony spacer San Giovani! Może nigdy go nie zobaczę, a jak cudnym mi się dziś wydał! Cała góra luciolami oświecona, miasto $\mathrm{w}$ dali migające i przezierające się w zwierciadlanych wodach! Te miejsca nie są zupełnie martwemi, dołączyć mogę do nich kilka wspomnień mniej smutnych i gorzkich; w tem miejscu często czytam Montego, Sylwia Pelica, który mię więcej niż dawniej zachwycił, nie tylko, że w oryginale jest piękniejszym, lecz że ciągle myślałam o biednych rodakach, którzy miejsce jego zajmują na Piorunowie (w Szpilbergu). O! czy wszyscy z równą uległością znoszą te cierpienia? czy nie upadli pod ich brzemieniem? Te pytania i myśli wesołemi nie były, a jednak ich wspomnienie przykrem mi nie jest; bo stokroć jest słodziej wspominać łzy współczucia, niż radość i uśmiechy, patrząc na te cudne krajobrazy, na te piękności i wesele całej natury. Jeszcze więcej bolałam nad tymi, którym wszystkie słodycze życia wydarto, i z całą gorącością ducha powtarzałam tu psalm Dawida pięknie przez Sylwia przełożony ${ }^{15}$.

Jak można się domyślać, obecny w zapisie ton smutku i żalu z powodu wyjazdu świadczy o prawdziwym zauroczeniu pamiętnikarki górską przestrzenią. Szczególną uwagę zwraca połączenie opisu położenia Bagni di Lucca z wątkami

\footnotetext{
14 Ibidem, s. 13-14.
}

15 Ibidem, s. 14. 
patriotycznymi. Z przytoczonej relacji wynika bowiem, że oddawanie się lekturze Le mie prigioni (1832) Silvia Pellica (1789-1854) w otoczeniu urokliwych widoków skłoniło polską podróżniczkę do rozmyślań o rodakach więzionych w brneńskim Spielbergu (dzis. Špilberk). Wydaje się jednak, iż obcowanie z naturą i doświadczanie jej piękna złagodziło te jakże przygnębiające rozważania. Majestat podziwianej scenerii wzbudził w niej również religijne uczucia, którym dała wyraz w samotnej, żarliwej modlitwie.

Mimo że przywołane fragmenty poświęcone apenińskim krajobrazom zajmują nieznaczną część relacji wspomnień Anieli Walewskiej, to jednak zasługują na przypomnienie oraz wnikliwą analizę i interpretację. Są bowiem świadectwem indywidualnego, kobiecego przeżywania świata natury, które nie tylko wzbogaci literaturę podróżniczą epoki romantyzmu, lecz także pogłębi naszą wiedzę na temat historii górskich wojaży Polek w tymże okresie.

\section{Bibliografia}

Berkan-Jabłońska M., Weredyczki, sawantki, marzycielki, damy... W kręgu kobiecego romantyzmu. Studia i szkice z kultury literackiej kobiet okresu międzypowstaniowego, Łódź 2019.

Bernardini L., Polska podróżniczka w Lukce w czasach ekscentrycznego księcia Karola Ludwika Burbona, [w:] Iter Italicum. Sztuka i historia/Arte e Storia, red. M. Wrześniak, Warszawa 2011.

Bożenna [Walewska A.], Wycieczka z Szczawnicy do Szmeks, „Dziennik Warszawski” 4, 1854, nr 338.

Czarkowski L., Pseudonimy i kryptonimy polskie, Wilno 1922.

Encyklopedia powszechna [S. Orgelbranda], t. 9, Warszawa 1901.

Estreicher K., Bibliografia polska XIX stulecia, t. 5, Kraków 1880.

Kolbuszewska E., Romantyczne przeżywanie przyrody. Znaczenia, wartości, style zachowań, Wrocław 2007.

Kowalczyk M.E., Zagraniczne podróże Polek w epoce oświecenia, Łomianki 2019.

Kudelska D., Juliusz Stowacki i sztuki plastyczne, Lublin 1997.

Minkowiecki E., Wykaz pseudonymów używanych przez autorów polskich, Warszawa 1881.

Odrowąż W. [Walewska A.], Kilka chwil we Włoszech w latach 1847-1848, Poznań 1850.

Stownik pseudonimów i kryptonimów pisarzy polskich oraz polski dotyczacych, t. 3, oprac. A. Bar, Kraków 1938.

Stownik pseudonimów pisarzy polskich, red. E. Jankowski, t. 1, Wrocław 1994.

Wrześniak M., Florencja-muzeum. Miasto i jego sztuka w oczach polskich podróżników, Kraków 2013.

Zbrzeźniak M., Polskie peregrynantki we Wtoszech w latach 1815-1848. Portret Italii, jej kultury i mieszkańców, [w:] Życie prywatne Polaków w XIX wieku. „Portret kobiecy”. Polki w realiach epoki, t. 1, red. M. Korybut-Marciniak, M. Zbrzeźniak, Łódź-Olsztyn 2014. 